\title{
Articles
}

\section{Judicial Self-Government as Experimental Constitutional Politics: The Case of Turkey}

\author{
By Başak Çalı \& Betül Durmuş
}

\begin{abstract}
This article traces the evolution of judicial self-government practices (JSG) in Turkey and argues that the frequent changes in JSG are part of a broader trajectory of experimental constitutional politics. The Council for Judges and Prosecutors has experienced sharp turns since its establishment in 1961, respectively in 1971, 1982, 2010, 2014 and 2017. During this period, Turkey experienced different forms of judicial councils ranging from co-option, hierarchical and executive controlled judicial council models to a more pluralistic model. The Justice Academy of Turkey has also not been immune from this experimentalism. The article discusses the endogenous relationship between these often short-lived experiments of JSG and their impacts on the independence, accountability, and legitimacy of the judiciary and public confidence in the judiciary. The article then turns to the repercussions of JSG on separation of powers and democratic principle. It focuses on the implications of the ambiguous position of the Council in the state structure for the separation of powers, and the revived debate on democratic legitimacy of JSG after the 2017 constitutional amendments.
\end{abstract}

\footnotetext{
* Başak Çalı is Professor of International Law at Hertie School of Governance, and the Director of the Center for Global Public Law, Koç University. Email: bcali@ku.edu.tr. The research leading to this article has received funding from the European Research Council (ERC) under the European Union's Horizon 2020 research and innovation programme (grant no. 678375- JUDI-ARCH-ERC-2015-STG). Betül Durmuş is PhD Candidate in Public Law and Research Assistant in Public International Law at Koç University. Email: bdurmus13@ku.edu.tr.
} 


\section{A. Introduction}

This article traces the genesis and the subsequent development of judicial self-government (JSG) in the Turkish legal and political context. It does so by highlighting the critical junctures of JSG practices across time, starting from the 1960 Constitution and ending with the latest constitutional amendments in 2017. The paper shows that the evolution of JSG in Turkey is part of a larger trajectory of constitutional politics, marked by contestation with regard to the appropriate role of the judiciary in the Turkish political context. Moves to strengthen and weaken JSG and, in turn, how these impact on judicial independence, accountability, legitimacy, public confidence in the judiciary and separation of powers can only be understood in the broader context of Turkey's constitutional trajectory, which has taken multiple sharp turns since 1960.

Since the establishment of the Republic, Turkey has experimented with diverse forms of JSG ranging from no JSG, a co-option judicial council model, a hierarchical judicial council model, the executive controlled judicial council model and a pluralist judicial council model, under different political conditions. It must, however, be borne in mind that all these models have a 'Turkish' flavor to them and incorporate a number of novelties. Each time a new model has been introduced, it has had its ardent supporters, but it has also been subject to heated debates, in particular, with a specific emphasis on the implications of these different models for judicial independence and the separation of powers. JSG reforms invariably took place against a larger background of transformative constitutional moments and not as reforms that were brought forward following long and wide-ranging consultations, and reflection. Significantly, only in the space of the last seven years, JSG has evolved from strong, independent, and non-hierarchical JSG to strong executive control in a strictly hierarchical model. The reforms, old and new, have attracted deep skepticism regardless of the various merits of the reforms on paper.

In recent times, JSG reforms have taken place against the background of the rise of, what some have framed as the gradual entrenchment of a competitive authoritarian form of governance, under the rule of the Justice and Development Party (AKP) in Turkey since 2002 and the prevalence of factional judicial politics that ensued in the same period. ${ }^{1}$ Since the state of emergency was declared following the failed coup attempt of July 2016, one quarter of the judiciary has been purged on the grounds that they had links to, or contact with, or were members of the Fetullahist Terrorist Organization ("FETO/PDY") that allegedly carried out the failed coup attempt. ${ }^{2}$ The very recent changes in JSG, thus, are

\footnotetext{
${ }^{1}$ Ergun Özbudun, Turkey's Judiciary and the Drift Toward Competitive Authoritarianism, 50 THE INTERNATIONAL SPECTATOR 42(2015); Berk Esen \& Sebnem Gumuscu, Rising competitive authoritarianism in Turkey, 37 THIRD WORLD QUARTERLY 1581(2016).
} 
direct responses to the dominance of the judiciary by what is now understood as a factional group with significant number of supporters in the judiciary.

In what follows, in part B, we discuss the trajectory of JSG against the background of larger constitutional and political developments in Turkey. In Part C, we highlight the endogenous nature of the changes in JSG and its impacts on independence, accountability, and legitimacy of the judiciary and public confidence in the judiciary. The frequent and fundamental changes to JSG in Turkey, however, renders it difficult, if not impossible, to trace the impact of each distinct JSG model on the independence, accountability, transparency, and legitimacy of the judiciary. The frequent experimentation with different models of JSG in Turkey points to the unconsolidated place of the judiciary in the Turkish constitutional and political landscape. In part D, we reflect on how the changes in JSG can be seen in terms of the separation of powers and democratic principle doctrines in the Turkish context, in particular amongst Turkish legal scholars. We show that the nature of JSG in Turkey remains deeply political and politicized despite the institutionalization of JSG under the Constitution since 1961.

\section{B. Forms and Rationales of Judicial Self-Government}

Turkish judicial system is a typical example of a continental system which is based on separation of civil and administrative jurisdictions. While the former includes civil and criminal first instance courts, regional civil courts and the Court of Cassation; the latter covers first instance administrative and tax courts, regional administrative courts and the Council of State.

2 The Economist, Turkey's purges are crippling its justice system (May 20, 2017) https://www.economist.com/news/europe/21722200-president-erdogans-drive-power-includes-putting-judgesunder-his-thumb-turkeys-purges-are; the Gülen movement emerged in the 1970s under the leadership of Fetullah Gülen, had once seen as a liberal Islamist movement supporting the idea of inter-religious dialogue and modernism, and had been distinguished from other fundamental Islamist groups. See Niyazi Öktem, Religion in Turkey, 2002 Brigham Young University LAW ReVIeW 371 (2002).; Bülent Aras and Ömer Çapa, Fethullah Gülen and His Liberal 'Turkish Islam' Movement, in ReVolutionaRIES AND REFORMERS: CONTEMPORARY ISLAMIST MOVEMENTS IN THE MIDDLE EAST (Rubin Barry ed., 2003).; İştar B. Gözaydın, The Fethullah Gülen movement and politics in Turkey: a chance for democratization or a Trojan horse?, 16 DEMOCRATIZATION 1214 (2009). Beginning from the 1990s, the movement gained supporters and sympathisers in the social, political, and economic life in Turkey and abroad. Educational institutions set up by the movement in Turkey and abroad were central to its popularity. The linkage between the movement and the Justice and Development Party (AKP) became apparent when the supporters of the movement were able to hold important positions in the bureaucracy, judiciary, and security forces under the long rule of the AKP from 2002. This partnership ended in December 2013. When the alliance was broken, the AKP first argued that the movement had formed a "parallel state", and later the movement was recognized as a terrorist organization. See the history of the movement and its relations with the AKP government in Filiz BaşkanCanyaş \& F. Orkunt Canyaş, The interplay between formal and informal institutions in Turkey: the case of the Fethullah Gülen community, 52 MIDDLE EASTERN STUDIES 280 (2015); Hakkı Taş, A history of Turkey's AKP-Gülen conflict, MEDITERRANEAN POLITICS (2017). 
The powers regarding court administration and the career of judges are shared among the Council for Judges and Prosecutors ("HSYK"), the Justice Academy, and supplementary JSG bodies including the Justice Commissions and the supreme courts. These bodies are clear examples of JSG since they are mostly composed of judges. The Ministry of Justice, on the other hand, previously held and continues to hold important powers on court administration and judicial government, but this does not qualify as a form of judicial selfgovernment. ${ }^{3}$ The Ministry can be regarded as an affiliated body holding a key role in the shaping of JSG, particularly through its dominant positions in the Council and the Academy.

\section{The Council for Judges and Prosecutors}

The Council for Judges (which was later merged with the Council for Prosecutors) was established as a constitutional body in the 1961 Constitution that was enacted in the aftermath of the 1960 military coup. Since then, it has preserved its constitutional status. Although it has been more than forty years since its establishment, its composition, qualifications, the election procedures of its members, and its powers have been subject to changes in critical political junctures. As the Venice Commission noted in 2010, Turkey has a tradition of politicizing the administration of the Council. ${ }^{4}$ This can be seen in the changes that have been introduced to the composition and the powers of the Council respectively in 1971, 1982, 2010, 2014, and 2017. Of these changes only the ones in 2014 were brought forward by way of legislation, the rest were constitutional amendments. How the judiciary governs itself has, therefore, been rearranged at each constitutional juncture (with the exception of 2014 amendments).

\footnotetext{
${ }^{3}$ There are judges who serve administrative tasks at the Ministry of Justice. The Minister of Justice is entitled to appoint judges, with their consent, to carry out temporary or permanent tasks in "the central, affiliated, or relevant institutions of the Ministry of Justice. According to Article 159/12 Constitution, "Those judges and public prosecutors working in administrative posts of judicial services shall be subject to the same provisions as other judges and public prosecutors. Their categories and grades shall be determined according to the principles applying to judges and public prosecutors, and they shall enjoy all the rights accorded to judges and public prosecutors.' Although judges working in administrative posts enjoy the same rights as other judges with judicial functions, this does not suffice to regard the Ministry of Justice as a JSG body since Article 140/7 of the Constitution also stipulates that they are "attached to the Ministry of Justice" with regard to their administrative duties. In addition to their attachment to the Ministry, it is also difficult to trace the impact of their role. As of March 2017, 394 judges work at the central institution of the Ministry at different posts. See http://www.hsk.gov.tr/Eklentiler/Dosyalar/962736e7-d42b-4930-bd91-ec352fea7891.pdf.

${ }^{4}$ Interim Opinion on the Draft Law on the High Council for Judges and Prosecutors of Turkey, European Commission for Democracy through Law (Venice Commission), CDL-AD(2010)042, (Dec. 20, 2010), par. 18.
} 


\section{The 1924 Constitution: Absence of JSG}

A proper explanation for the rationale of the establishment of the Council in 1961 requires looking at the role of the judiciary in the aftermath of the enactment of the 1924 Constitution of the Turkish Republic. The 1924 Constitution provided for the judicial function to be carried out by "independent courts" and recognized the independence of judges from intervention by other branches of the state. ${ }^{6}$ It did not, however, secure the tenure of judges in the Constitution. In effect, the Constitution allowed for the dismissal of judges by ordinary laws by stating that "judges cannot be dismissed except by circumstances prescribed by law." ${ }^{7}$ Other professional rights of the judges including the organization of their duties and salaries were also delegated to ordinary legislation. ${ }^{8}$

The Law on Judges of $1934^{9}$ established the Council of Separation ("Ayırma Meclisi") and endowed it with powers to advise the Minister of Justice on the promotion of judges. This Council was chaired by the President of the Court of Cassation. The Chief Public Prosecutor, four members of the Court of Cassation, and four Directors of the Ministry of Justice became the other members of the Council of Separation. This, however, was not a judicial council in today's sense, because its powers were quite limited, and the Ministry of Justice retained the sole authority deciding on the appointment and promotion of judges.

Due to these features, many commentators characterize the protections afforded to judicial independence in the 1924 Constitution as weak. ${ }^{10}$ During the Republican People's Party (CHP) single party rule between 1923 and 1950, however, this lack of constitutional protection for the judiciary did not result in serious tensions between the executive and the judiciary. This is attributed to the absence of a distinction between the objectives of the single party rule and the judiciary, where the latter mirrored the former. ${ }^{11}$ The

\footnotetext{
${ }^{5}$ Article 8 of the 1924 Constitution; The English version of the full text can be found in Edward Mead Earle, The New Constitution of Turkey, 40 POLITICAL SCIENCE QUARTERLY (1925) http://genckaya.bilkent.edu.tr/1924cons titution.pdf.

${ }^{6}$ Article 54 of the 1924 Constitution.

${ }^{7}$ Article 55 of the 1924 Constitution.

${ }^{8}$ Article 56 of the 1924 Constitution.

${ }^{9}$ Law no. 2556, enacted on 4/7/1934.

${ }^{10}$ Ergun Özbudun, 1924 AnaYASASı 57 (2012); Kemal Gözler, 1924 Teşkılatı Esasiye Kanunu http://www.anayasa. gen.tr/tek-1924.htm.

${ }^{11}$ Ceren Belge, Friends of the Court: Republican Alliance and Selective Activism of the Constitutional Court of Turkey, 40 L. AND SOC'Y REV.653 (2006).
} 
weakness of the constitutional framework regarding the judiciary was seen in a more negative light when the multi-party regime was adopted in 1950, and a new party, the Democrat Party (DP) came into power through elections. Subsequently, the absence of security of tenure for judges led to important political crises when the newly elected DP government used ordinary laws to purge senior judges, which it saw as supporters of the old regime, that of the CHP. In 1953, legislation passed made it possible to send any civil servant who served more than 30 years into early retirement. ${ }^{12}$ Many judges serving in the ordinary courts were forced to retire due to this. ${ }^{13}$ In 1954, the time limit for retirement was lowered to 25 years allowing the purge to also cover members of the Court of Cassation. ${ }^{14}$

\section{The 1961 Constitution: The Establishment of the Judicial Council}

The DP rule ended with the military coup of 1960. The 1961 Constitution, well known for its concern for imposing checks on elected governments under the multi-party regime ${ }^{15}$, introduced significant protections for the independence of the judiciary from political meddling. Unlike the 1924 Constitution, the 1961 Constitution was based explicitly on the principle of separation of powers, and established for the first time "counter-majoritarian institutions ${ }^{\prime 16}$ including the Constitutional Court, the High Council of Judges (the Council), the National Security Council, and the State Planning Organization. Many scholars refer to Ran Hirschl's "hegemonic preservation thesis" ${ }^{17}$ to explain, in particular, the establishment of the Constitutional Court, and the constitutional protections afforded to the judiciary under the 1961 Constitution. ${ }^{18}$ This thesis also seems relevant for the establishment of the Council. The rationale for establishing the Council was to insulate decisions on the career

\footnotetext{
12 ERIC ZÜRCHER, TURKEY: A MODERN HISTORY 241 (2004).

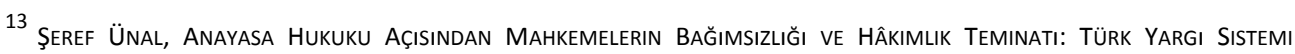
ÜZERINDE KARŞILAŞTIRMALI HUKUK AÇISINDAN BIR İNCELEME 72 (1994).

${ }^{14}$ Id.

${ }^{15}$ Ceren Belge, supra note 11, at 663.

${ }^{16}$ Id.

${ }^{17}$ Ran Hirschl, The Political Origins of Judicial Empowerment through Constitutionalism: Lessons from Four Constitutional Revolutions, 25 LAW \& SOC. INQUIRY 91 (2000).

${ }^{18}$ Güneş Murat Tezcür, Judicial Activism in Perilous Times: the Turkish Case, 43 LAW \& Soc'Y REv. 305, 309 (2009); Ceren Belge, supra note 11, at 664; Ergun Özbudun, Political Origins of the Turkish Constitutional Court and the Problem of Democratic Legitimacy, 12 EUR. PUB. L. 213 (2006); Hootan Shambayati and Esen Kirdiş, In Pursuit of Contemporary Civilization: Judicial Empowerment in Turkey, 62 POLITICAL RESEARCH QUARTERLY 767, 769 (2009).
} 
of judges from the control or influence of the elected governments, as was witnessed by the DP purges of judges.

The Constitution assigned broad self-governance powers to the Council by stating that the Council had "the power to decide about all personal matters of the judges." ${ }^{19}$ The Council was composed of eighteen regular and five substitute members. Six regular and two substitute members were elected by the General Assembly of the Court of Cassation; six regular members and one substitute member were elected by the first category judges among themselves; six regular and two substitute members were elected by the National Assembly and the Senate. The candidates for membership were selected from individuals who served as judges in the high courts or were qualified to serve in such courts. ${ }^{20}$ The Council could elect its Chair from among its members. ${ }^{21}$ The Minister of Justice might attend the meetings of the Council, but could not vote. ${ }^{22}$ Limiting the involvement of the Minister in such a way had been a great sign of the Council's autonomy, and a strong preference for judicial self-government in general.

This composition shows that the 1961 Constitution adopted the co-option model. All the members of the Council were elected amongst judges. However, the role of the parliament in the election procedure prevented the Council being characterized as a strict case of cooption. Additionally, a balance had been sought between the high judiciary and the first category judges to prevent the Council having a hierarchical model.

\section{The 1971 Constitutional Amendments: Introducing the Ministry in the Council}

The 1961 Constitution and the return to civilian rule was not long lived. Not only was the Constitution amended seven times between 1969 and 1974, the government was forced to resign by a military intervention in 1971, claiming social unrest and economic failure under their rule. The post 1971 amendments to the Constitution, blamed the autonomous and decentralized outlook of the 1961 Constitution for governance failures and aimed to strengthen the powers of a centralized executive. This outlook also brought important changes to the composition of the Council and its relationship with the Minister of Justice. First, the total number of members was decreased to eleven regular and three substitute members. Secondly, all Council members were to be elected by the General Assembly of the Court of Cassation from among its own members. Thirdly, the amended Constitution

\footnotetext{
${ }^{19}$ Article $144 / 1$ of the 1961 Constitution.

${ }^{20}$ Article $143 / 1$ of the 1961 Constitution.

${ }^{21}$ Article $143 / 2$ of the 1961 Constitution.

${ }^{22}$ Article $143 / 6$ of the 1961 Constitution.
} 
set out that the Minister of Justice could attend the meetings of the Council "in case he deems it necessary." The 1971 amendments further gave the Minister of Justice the power to chair meetings and the right to vote. Thus, with the 1971 amendments, the Council turned into a hierarchical model, and its earlier autonomy was weakened.

\section{The 1982 Constitution: A Dependent and Hierarchical Judicial Council}

The civilian rule was interrupted a third time by the 1980 military coup. The 1982 Constitution that followed reorganized the judicial council carving out an even stronger role for the executive in all matters with respect to the administration of the judiciary. First, and most importantly, the Minister of Justice became the Chair, and the Undersecretary of the Ministry of Justice became an ex officio member of the Council. ${ }^{23}$ Secondly, the President of the Republic was given powers to appoint members. Thirdly, the total number of members decreased to seven regular and two substitute members. Accordingly, the President of the Republic was given the power to appoint three regular and three substitute members from the candidates proposed by the General Assembly of the Court of Cassation, and two regular and two substitute members from the candidates proposed by the General Assembly of the Council of State. ${ }^{24}$ Another crucial change that occurred around this time was that the previously separate Councils for judges and prosecutors were joined in one institution and the Council thus became the High Council of Judges and Prosecutors.

The autonomy of the Council, already weakened by the 1971 amendments, was almost entirely abolished by the 1982 Constitution. This was in line with the broader rationale of the 1982 Constitution, which was to further strengthen the executive. The Council was no longer responsible for "all personal matters." Rather, the powers of the Council were explicitly listed as "the admission of judges and public prosecutors of civil and administrative courts into the profession, appointment, transfer to other posts, the delegation of temporary powers, promotion, and promotion to the first category, decisions concerning those whose continuation in the profession is found to be unsuitable, the imposition of disciplinary penalties and removal from office." ${ }^{25}$ Although the Council had the authority to impose disciplinary sanctions, supervision or investigation of the judges was left outside the powers of the Council, and was given to the Board of Inspectors that sit in the Ministry of Justice. ${ }^{26}$

${ }^{23}$ Article 159/2 of the 1982 Constitution (the first version).

${ }^{24}$ Id.

${ }^{25}$ Article $159 / 3$ of the 1982 Constitution (the first version).

${ }^{26}$ Article 15 of the Law on the Ministry of Justice (Law no. 2992, 29/3/1984). 


\section{The 2010 Constitutional Amendments: Non-hierarchical and Pluralistic Council}

The social legitimacy of the 1982 Constitution has long been suspect. Not only was the constitution the product of a violent military coup that perpetrated gross human rights violations, but its vision reflected an anti-democratic world view. There have, therefore, long been calls to have a "civil constitution" underpinned by unequivocal commitments to democracy, human rights and the rule of law. Between 1982 and 2010, the Constitution was amended ten times. Although diverse in terms of focus, they include amendments that substantively increased the fundamental rights protections under the Constitution. None of these amendments, however, touched the powers of the Council until 2010. The Justice and Development Party, which came into power in 2002, turned to the design of the Council in its constitutional amendment package of 2010. The government presented the 2010 package as a continuation of the increased emphasis on human rights and democracy in the Constitution. The package included important provisions on protection of fundamental rights and freedoms, curbing the power of military courts, and lifting the immunity of the military officers responsible for the 1980 coup.

The 2010 amendments, regarding the composition of the Council, increased the number of its members and identified multiple ways of election to the Council. The total number of members increased to twenty-two regular and twelve substitute members. Along with the two supreme courts, and the President of the Republic, the first category judges and prosecutors as well as the General Assembly of the Justice Academy became eligible to elect members to the Council. As the Constitution sets out,

For a term of four years, four regular members of the Council, the qualities of whom are defined by law, shall be appointed by the President of the Republic from among members of the teaching staff in the field of law, and lawyers; three regular and three substitute members shall be appointed by the General Assembly of the High Court of Appeals from among members of the High Court of Appeals; two regular and two substitute members shall be appointed by the General Assembly of the Council of State from among members of the Council of State; one regular and one substitute member shall be appointed by the General Assembly of the Justice Academy of Turkey from among its members; seven regular and four substitute members shall be elected by civil judges and public prosecutors from among those who are first category judges and who have not lost the qualifications required for being a first category judge; three regular and two substitute members shall be elected by administrative judges and public prosecutors from among 
those who are first category judges and who have not lost the qualifications required for being a first category judge. ${ }^{27}$

The 2010 changes altered the hierarchical model of the Council by opening places in the Council for the first category civil and administrative judges and prosecutors, members of law schools and lawyers as well as members of the Justice Academy. Significantly, for the first time in the history of the Council, the first category judges and prosecutors made up the majority of the Council, out-numbering members of the high judiciary. The role of the Ministry of Justice as the Chair, and the Undersecretary of the Ministry as an ex officio member of the Council, however, remained the same.

The 2010 amendments also increased the powers of the Council by transferring the power of disciplinary supervision and investigation of judges to the Board of Inspectors of the Council from those sitting at the Ministry of Justice. ${ }^{28}$ The institutional structure of the Council changed as the Council began to work in three chambers. ${ }^{29}$ The amendments also prevented the Minister of Justice from participating in the work of the chambers of the Council. ${ }^{30}$ A General Secretariat was established for the Council. The Secretary General was appointed by the President of the Council, i.e. the Minister of Justice, among three candidates proposed by the Council from among the first category judges and prosecutors. ${ }^{31}$ Right after the entry into force of these amendments, the Law on the High Council of Judges and Prosecutors was adopted. This law ensured that the Council could run its own budget and have its own staff and premises. ${ }^{32}$

The 2010 amendments attracted significant public attention and divided the Turkish legal community as to their underlying political purpose. ${ }^{33}$ Some welcomed the amendments

${ }^{27}$ Emphasis added. See Article 159/3 of the 1982 Constitution as amended on September 12, 2010.

${ }^{28}$ Article 159/9 of the 1982 Constitution as amended on September 12, 2010.

${ }^{29}$ Article 159/2 of the 1982 Constitution as amended on September 12, 2010. The competences of each chamber have been regulated in article 9 of the Law on the High Council of Judges and Prosecutors (Law no. 6087, $11 / 12 / 2010)$

${ }^{30}$ Article 159/7 of the 1982 Constitution as amended on September 12, 2010.

${ }^{31}$ Article 159/11 of the 1982 Constitution as amended on September 12, 2010.

${ }^{32}$ Article 5 of the Law on High Council of Judges and Prosecutors presents the organization of the HSYK and Article 44 of the same law states that "The Council is governed with its own general budget."

${ }^{33}$ For a review of the whole constitutional amendment package see Esin Örücü, The Turkish Constitution Revamped Yet Again, 17 EUR. PUB. L. 11(2011). 
pointing to their overall "liberalizing" and "democratizing" effect. ${ }^{34}$ Others argued that the amendments would result in "the centralization of power in the hands of one party", 35 and were a part of a "court-packing plan." ${ }^{36}$ For the latter group, the 2010 amendments represented the Justice and Development Party's attempt to reengineer the judiciary in order to bring it in line with its political outlook, not unlike the developments under the DP rule in the 1950s. The emphasis on democratizing the Council was seen as a screen to conceal and make palatable the larger political plan aimed at changing the guardians of the judiciary.

\section{The December 2013 Corruption Crisis and the 2014 Legal Changes}

In an unexpected turn of events, the 2010 amendments introducing a non-hierarchical form of JSG did not last long. The so-called corruption crisis of December 2013 not only revealed the political deals behind the 2010 amendments, but also laid bare that the judiciary was not going to be immune from the fallout between President Erdoğan and cleric Fetullah Gulen and his movement, a longtime supporter of Erdogan and his government.

The crisis started with the detention of the sons of three acting Ministers, some businessmen and a Mayor on 17 December 2013 for crimes of corruption. This was followed by further investigations on 25 December 2013 and included charges against wellknown businessmen and, the then Prime Minister, Recep Tayyip Erdoğan's son. The government responded to this by saying that these investigations and subsequent charges were pursued by 'a parallel structure' that had infiltrated the police, and the security forces led by the cleric Fetullah Gulen.

In order to prevent possible operations conducted by the police that may be part of this 'parallel structure', the government changed the "Regulation on the Judicial Police" on 21 December 2013. According to the new regulation, police officers involved in criminal investigations conducted by public prosecutors, were obliged to inform administrative authorities about the investigation. This development was criticized by the Council with a press release suggesting that the new version of the regulation weakened the

\footnotetext{
${ }^{34}$ Aslı Bâli, The Perils of Judicial Independence: Constitutional Transition and the Turkish Example, 52 VIRGINIA J. INTL. L. 235 (2012); Aslı Bâli, Unpacking Turkey's 'Court-Packing' Referendum, MIDDLE EAST RESEARCH AND INFORMATION PROJECT (Nov. 5, 2010) http://www.merip.org/mero/mero110510.

35 Ceren Coşkun, Don't sweeten the bitter pill of an illiberal democracy, OpenDemocracy (Sep. 10, 2010) https://www.opendemocracy.net/ceren-coskun/don\%E2\%80\%99t-sweeten-bitter-pill-of-illiberal-democracy .

${ }^{36}$ Can Yeginsu, Turkey Packs the Court, THE NeW York ReVIEW OF Books (Sep. 22, 2010) http://www.nybooks.com /contributors/can-yeginsu/.
} 
independence of the judiciary. ${ }^{37}$ Taking this as a signal that the newly composed nonhierarchical Council may also be part of the 'parallel structure', the government turned its attention to amending the current law on the Council with the aim of increasing the powers of the Ministry of Justice within it. ${ }^{38}$ Due to the cumbersome process of constitutional amendment and the perceived urgency of the matter, the government introduced a number of amendments through ordinary law.

After several attempts, Law no. 6524 entered into force in 2014, amending some provisions of the relevant laws on the judiciary including the Law on Judges and Prosecutors, the Law on the High Council of Judges and Prosecutors, and the Law on the Justice Academy of Turkey. Two amendments brought by this new law were particularly important with regard to JSG. First, the new law gave power to the Minister of Justice to appoint the members of the chambers of the Judicial Council. ${ }^{39}$ Secondly, a provisional article in the new law terminated the existing positions, in the Council, of the Secretary General, assistant secretaries general, the Chairman of the Board of Inspectors and the Vice-Chairmen, Council inspectors, reporting judges, and the administrative personnel in the Council at that time and gave the power to the Minister of Justice to appoint new people to these positions. ${ }^{40}$ With the entry into force of the new law, these two amendments were implemented promptly. Although the Constitutional Court annulled these provisions on the basis of unconstitutionality, this judgement did not affect the administrative decisions of the Minister on the new appointments. ${ }^{41}$

These amendments pointed to the concerns of the government that a significant number of judicial positions were occupied by individuals who were loyal to, supporting or sympathizing with the Gulen movement. They also confirmed the fears of those critical of the 2010 amendments that the government's proposal of redesigning JSG was motivated by the intention of bringing judges to power who were loyal to the government. Once the

\footnotetext{
${ }^{37}$ At that time Prime Minister Erdoğan strongly opposed this action of the HSYK. See Hurriyet Daily News, I would judge the Supreme Council of Judges and Prosecutors if I had the authority (Dec. 27, 2013) http://www.hurriyetdailynews.com/i-would-judge-the-supreme-council-of-judges-and-prosecutors-if-i-hadauthority-turkish-pm. aspx?pagelD=238\&nID=60233\&NewsCatID=338.

${ }^{38}$ See the effects of the corruption crisis on the Council in Ergun Özbudun, Pending Challenges in Turkey's Judiciary, GLOBAL TURKEY IN EUROPE (2015).

39

${ }^{40}$ Article 39 of the Law no 6524.

${ }^{41}$ Constitutional Court, E. 2014/57, K. 2014/81 (14 April 2014). According to article 153 of the Constitution, the judgments of the Constitutional Court are not retroactive. This means, the Court cannot abrogate the decisions taken before the date of the judgment.
} 
loyalty of Gulenist judges became suspect, the 2010 amendments no longer served their purpose.

\section{The 2017 Constitutional Amendments: Increased Control of the President of the Republic in Judicial Governance}

The 1982 Constitution created the office of the Presidency of Turkey as the neutral and non-partisan guardian of the state elected by the Parliament. However, the role and powers of the President have been contested, particularly, by the right-wing conservative political circles demanding for a popularly elected President. Eventually in 2007, the election procedure of the President was amended. The 2007 constitutional amendments adopted through a referendum - enabled the President to be elected directly by public vote. ${ }^{42}$ However, the neutral standing of the President towards the political parties remained until the 2017 constitutional amendments.

The 2017 constitutional amendments concern transformation of the Turkish constitutional system into a form of partisan presidentialism, and have been discussed in the broader context of the repercussions of this for the separation of powers, and checks and balances. ${ }^{43}$ Reform of the Council was an important part of the 2017 constitutional amendments, and it cannot be separated from this broader constitutional arrangement.

According to the amendments entered into force on 16 April $2017,{ }^{44}$ the Council shrunk significantly and is now composed of thirteen members instead of twenty-two members. The President of the Turkish Republic (who after the 2017 constitutional amendments can also be the active head of a political party whilst acting as President) appoints three members from among first category civil judges and prosecutors, and one member from among administrative judges and prosecutors. The Grand National Assembly elects three members from the Court of Cassation, one member from the Council of State, and three

42 Law no 5678, enacted on October 21, 2007 amending article 101 of the 1982 Constitution.

43 Bertil Emrah Oder, Turkey's ultimate shift to a presidential system, CONSTITUTIONNET (Jan. 31, 2017) http://www.constitutionnet.org/news/turkeys-ultimate-shift-presidential-system-most-recent-constitutionalamendments-details ; Felix Petersen \& Zeynep Yanaşmayan, The Final Trick? Separation of Powers, Checks and Balances, and the Recomposition of the Turkish State, Verfassungsblog (Jan. 28, 2017) http://verfassungsblog.de/the-final-trick-separation-of-powers-checks-and-balances-and-the-recomposition-ofthe-turkish-state/; Ozan Varol, Presidentialism in Turkey: Is It Already Here?, CONSTITUTIONNET (Nov. 24, 2015) http://www.constitutionnet.org/news/presidentialism-turkey-it-already-here

${ }^{44}$ The majority of the amendments will enter into force either after the start of the proceedings for the next general and presidential elections, or when the next National Assembly and President of the Republic begin to work. The amendments concerning the Council for Judges and Prosecutors entered into force right after the results of the referendum had been published at the official gazette. See Article 18 of the Law No. 6771. 
members who are lawyers and law professors. The Minister of Justice continues to be the Chair of the Council, and the Undersecretary of the Ministry of Justice remains an ex-officio member.

The shift between the 2010 and 2017 amendments are remarkable in the sense that whilst the former enabled the election of the Council by the judiciary, the latter ended this and vested the power to appoint and elect judicial members to the President of the Republic and the National Assembly. It further gave these two organs power to elect members outside the judiciary, as lawyers and law professors continue to be eligible for the Council membership.

In sum, the experimental journey of the election and the composition of the Council reflects the contested nature of the role of the judiciary in the Turkish constitutional landscape. Although the Council had been established as a strong guardian of judicial independence and vested with wide powers on the careers of judges in 1961, it did not remain as such due to many interventions, particularly to its composition (see table on the following page). 
The Composition of the Judicial Council

\begin{tabular}{|c|c|c|c|c|}
\hline & $\begin{array}{l}\text { Hierarchy } \\
\text { (Senior Judges: } \\
\text { Junior Judges) }\end{array}$ & $\begin{array}{l}\text { Co-option or } \\
\text { Mixed } \\
\text { (Judicial: } \\
\text { Executive: } \\
\text { Others) }\end{array}$ & $\begin{array}{l}\text { The Actor(s) } \\
\text { Appointing/Electing } \\
\text { the Members }\end{array}$ & $\begin{array}{l}\text { The Role of the } \\
\text { Ministry of Justice }\end{array}$ \\
\hline 1924 & \multicolumn{4}{|c|}{ Absence of JSG } \\
\hline 1961 & $\begin{array}{l}\text { Hierarchical } \\
\qquad(12: 6)\end{array}$ & $\begin{array}{l}\text { Co-option } \\
\text { (18: None) }\end{array}$ & $\begin{array}{l}\text { Grand National } \\
\text { Assembly (6) + Peer } \\
\text { elections among } \\
\text { judges (12) }\end{array}$ & None \\
\hline 1971 & $\begin{array}{l}\text { Hierarchical } \\
\text { (11: None) }\end{array}$ & $\begin{array}{l}\text { Co-option } \\
\text { (11: None) }\end{array}$ & High Judiciary (11) & $\begin{array}{l}\text { Optional } \\
\text { chairmanship for } \\
\text { the Minister }\end{array}$ \\
\hline 1982 & $\begin{array}{l}\text { Hierarchical } \\
\text { (7: None) }\end{array}$ & $\begin{array}{l}\text { Mixed } \\
(7: 2)\end{array}$ & $\begin{array}{l}\text { President of the } \\
\text { Republic (7) } \\
\text { *among the } \\
\text { candidates elected } \\
\text { by the high judiciary }\end{array}$ & $\begin{array}{l}\text { Minister of Justice } \\
\text { (Chair with the } \\
\text { right to vote) } \\
\text { Undersecretary } \\
\text { (ex officio } \\
\text { member) }\end{array}$ \\
\hline 2010 & $\begin{array}{l}\text { Non-Hierarchical } \\
(5: 10)\end{array}$ & $\begin{array}{l}\text { Mixed } \\
(15: 2: 5)\end{array}$ & $\begin{array}{c}\text { President of the } \\
\text { Republic (4) + High } \\
\text { Judiciary (5) + Peer } \\
\text { elections among } \\
\text { junior judges (10) + } \\
\text { Justice Academy (1) }\end{array}$ & $\begin{array}{l}\text { Minister of Justice } \\
\text { (Chair without the } \\
\text { right to vote) } \\
\text { Undersecretary } \\
\text { (ex officio } \\
\text { member) }\end{array}$ \\
\hline 2017 & $\begin{array}{c}\text { Equal } \\
\text { Representation } \\
(4: 4)\end{array}$ & $\begin{array}{l}\text { Mixed } \\
(8: 2: 3)\end{array}$ & $\begin{array}{l}\text { President of the } \\
\text { Republic (4) + Grand } \\
\text { National Assembly } \\
\text { (7) }\end{array}$ & \\
\hline
\end{tabular}




\section{The Justice Academy of Turkey}

The Justice Academy of Turkey is part of the contemporary judicial reform packages introduced during the rule of the Justice and Development Party. It was founded in 2003 by ordinary law ${ }^{45}$ and became operational in 2004. Prior to its establishment, the preprofessional training of judges and prosecutors was conducted by the School for Candidate Judges and Prosecutors which was attached to the Education Department of the Ministry of Justice. ${ }^{46}$ It is noteworthy that upon its establishment the Academy, at least on paper, was given "scientific, administrative, and financial autonomy." 47

Parallel to the developments in the changes to the Council, the de jure autonomy of the Academy was weakened by the 2014 and 2016 legal amendments which increased the influence of the Ministry in its running. The 2014 changes vested the power to appoint the President and deputy-presidents of the Academy in the Minister of Justice. ${ }^{48}$ The composition of the General Assembly of the Academy also changed. Until 2014, the Academy had eight members from the Ministry of Justice, including the Minister, and nine members from the supreme courts (Court of Cassation, Council of State, High Military Court of Cassation, and High Military Court of Administration) as well as representatives of lawyers, law professors, and notaries. The 2014 changes increased the number of members from the Ministry from eight to eleven. It also gave power to the Minister to appoint six members from the first category civil and administrative judges and prosecutors to the General Assembly. ${ }^{49}$

The 2016 changes introduced an oral examination after completion of the pre-service training, whereas previously, only a written examination was required. ${ }^{50}$ The training program now lasts for two years and is divided into three periods: i) preparatory training, ii) internship, and iii) final training. ${ }^{51}$ The candidates are required to collect seventy points in total from the oral and written examinations in order to be appointed as judges or

${ }^{45}$ Law on the Justice Academy of Turkey (Law no. 4954, 23/7/2003).

${ }^{46}$ Law no. 3221, enacted on June 15, 1985.

${ }^{47}$ Article 4 of Law on the Justice Academy of Turkey.

${ }^{48}$ Article 9 of Law on the Justice Academy of Turkey.

${ }^{49}$ Article 12 of the Law on the Justice Academy of Turkey.

${ }^{50}$ Article $28 / 7$ and 8 of the Law on the Justice Academy of Turkey (the first version).

${ }^{51}$ Article 28 of the Law on the Justice Academy of Turkey. 
prosecutors. $^{52}$ The ones who fail the exams can request to be appointed to administrative tasks at the Ministry of Justice, otherwise, their candidacy is terminated. ${ }^{53}$ According to the changes of 2016 that introduced the oral exam after the pre-service training, the oral exam is conducted by a board chaired by the President of the Academy which includes four members from the Ministry, as well as two regular members and one substitute member from the law professors lecturing in the Academy. ${ }^{54}$ It is noteworthy that the judicial members of the General Assembly are not present in the examination board, and the high ranking officers of the Ministry hold the majority.

\section{Supplementary JSG Bodies}

The justice commissions and the supreme courts - the Court of Cassation and the Council of State - also have JSG duties, supplementing those of the Justice Academy and the Council, regarding supervision of judges.

The justice commissions in the civil jurisdiction are formed in every district where an assize criminal court exists. It is comprised of three judges (the chairperson, one regular member, one substitute member) appointed by the Council, and the public prosecutor of the district. ${ }^{55}$ The justice commissions in the administrative jurisdiction, on the other hand, are formed in the districts where the regional administrative courts are established. Two regular members and one substitute member of these commissions are administrative judges appointed by the Council. ${ }^{56}$ These commissions can be described as the administrative units supplementing the Ministry of Justice with regard to their duties managing the administrative personnel of courts and courthouses. However, they are also given the power to supervise both candidate and qualified judges, which makes them supplementary JSG bodies.

First, they provide appraisal of the performance and capabilities of the candidate judges at the end of their internship period. This appraisal is included in the files of each candidate. ${ }^{57}$

\footnotetext{
52 Article 28/13 of the Law on the Justice Academy of Turkey.

${ }^{53}$ Article 28/14 of the Law on the Justice Academy of Turkey.

${ }^{54}$ Article 28/10 of the Law on the Justice Academy of Turkey as amended on July 1, 2016.

${ }^{55}$ Article 113/a of the Law on Judges and Prosecutors.

${ }^{56}$ Article $113 / \mathrm{b}$ of the Law on Judges and Prosecutors.

${ }^{57}$ Article 11 of the Law on Judges and Prosecutors.
} 
Secondly, they decide on the extra working days and hours of the judges, ${ }^{58}$ and on compassionate leave if requested. ${ }^{59}$ Thirdly, and most importantly, they inform the Ministry of Justice when they consider that the actions of a judge necessitate a disciplinary investigation. $^{60}$

The Court of Cassation and the Council of State have JSG duties supplementing the performance evaluation system. After the review of the appeals against the decisions of the first instance courts, the chair of the chamber which reviewed the decision evaluates the conduct and performance of the judge and prepares an "appeal evaluation form." ${ }^{61}$ This type of evaluation was removed in 2011, but re-introduced in 2016 . The judges of the high courts scrutinize the conformity of the lower courts' decisions with the law, the length of the proceedings, and whether procedural rules are respected. The grades (very good, good, fair, bad, very bad) written in these forms are taken into account by the Council in the promotion of judges.

\section{Impact of Judicial Self-Government Experiments on the Independence, Accountability, Legitimacy, Transparency, and Confidence in the Judiciary}

In the Turkish context, it must first be underlined that the relationship between JSG and independence, accountability, legitimacy, transparency, and confidence (IALTC) in the judiciary is an endogenous relationship. That is, it is not only that the JSG experiments impact on these values, but that perceived or real IALTC also justifies the wide range of JSG experiments in practice. In what follows we seek to explore this two-way relationship.

\section{Judicial Self-Government and Judicial Independence}

Given the continuous interventions into the management of the judiciary in Turkish political history, it is no wonder that judicial independence has always been a debated issue in the political and public life of the country. For many, the relationship between JSG and judicial independence is an endogenous one. The lack of perceived or real independence of the judges affects how JSG arrangements have changed over time.

Judicial independence discussions in Turkey often center on the general lack of a judicial and institutional culture of independence. Commentators often point to a "state-centered

\footnotetext{
${ }^{58}$ Article 54 of the Law on Judges and Prosecutors.

59 Article 56 of the Law on Judges and Prosecutors.

${ }^{60}$ Article 62 of the Law on Judges and Prosecutors.

${ }^{61}$ Article 28 of the Law on judges and Prosecutors.
} 
mindset" within the judiciary that is inclined to protect the interests of the State over individual rights and freedoms. ${ }^{62}$ This state centric mindset, it is argued, has also been sustained via the procedures used to select and discipline judges. It is for this reason that when judges are seen as members of a former regime, from the perspective of the current political masters, that governments have actively sought to intervene in the Council to ensure a new alignment. Turkey also has a culture of creating special court systems outside of the ordinary judicial system, where the preferences of the executive are more easily reflected and executed by the judiciary, in particular against political opponents. The formation and functioning of the State Security Courts until their abolishment in $2004^{63}$ and the role of the criminal courts with special powers which were abolished in $2014,{ }^{64}$ and the current operation of criminal peace judgeships, single judge courts with powers to detain individuals, and censor media, are three examples of this. ${ }^{65}$

As seen in the recent debacles, the feebleness of judicial independence as a shared value not only centers on the executive practices seeking to institutionally control the judiciary, but also, as in the case of Gulenist judges, a particular group or ideology hijacking and controlling the judiciary for their own political ends. It has now been officially acknowledged that the high-profile cases of Ergenekon and Sledgehammer ("Balyoz") which targeted members of the military, politicians, journalists and academics in the mid2000s were sham trials organized by this network of judges. The police, prosecutors and the judiciary have been implicated in pursuing these trials without evidence and, in some instances, fabricating evidence. It was in response to this hijacking of the judiciary that the 2014 and 2017 changes to JSG were rolled back, increasing the power of the executive in judicial appointments. In the aftermath of the July 2016 failed coup attempt, the

\footnotetext{
62 Mithat Sancar \& Eylem Ümit Atılgan, "Adalet Biraz Es Geçiliyor...": Demokratikleşme Sürecinde Hakimler ve Savcllar, TESEV 120-151, http://tesev.org.tr/wp-content/uploads/2015/11/Adalet_Biraz_Es_Geciliyor_Demokratik lesme_Surecinde_Hakimler_Ve_Savcilar.pdf.; MITHAT SANCAR, YARGININ BAĞıMSIZLIĞı VE TARAFSIZLIĞı:“DEVLET AKLI” KıSKACıNDA HUKUK DEVLETI (Illetişim Yayınları. 2008); Vahap Coşkun, Turkey's Illiberal Judiciary: Cases and Decisions, 12 INSIGHT TURKEY 43(2010).

63

Law no 5170 enacted on May 7, 2004 repealing article 143 of the 1982 Constitution.

64 Law no 6526 enacted on March 6, 2014. See Hande Özhabeş, Assessment on Changes Regarding the Specially Empowered Judicial System in Turkey, TESEV PUBLICATIONS (2014) http://tesev.org.tr/wp-content/uploads/2015/1 1/Assessment_On_Changes_Regarding_The_Specially_Empowered_Judicial_System_In_Turkey.pdf.

65 Turkey: Opinion on the Duties, Competences and Functioning of the Criminal Peace Judgeships, Adopted by the Venice Commission at its 110th Plenary Session (Venice, 10-11 March 2017), European Commission for Democracy through Law (Venice Commission), (Mar. 13, 2017) http://www.venice.coe.int/webforms/docum ents/default.aspx?pdffile=CDL-AD(2017)004-e.
} 
government purged a quarter of the judiciary, indicating that they had connections to, or membership of, the Gulen movement. ${ }^{66}$

In Turkish legal literature, the dominant view, in terms of JSG arrangements, has been to support less of a role for the executive due to the lack of trust in the executive with to respect judicial independence. The role of the Ministry of Justice as the Chair of the Council since 1982 has, thus, been seen as violating the principle of judicial independence. ${ }^{67}$ Although there have been some arguments favoring the attendance of the Minister at the meetings of the Council as the representative of the executive branch which is responsible for court administration and the justice system, the Chairmanship role has been contested due to its real and perceived impact on judicial independence. ${ }^{68}$ The same concerns apply for the ex officio membership of the Undersecretary. ${ }^{69}$ The reports following the advisory visits of the European Commission, and the reports of the Venice Commission, the Commissioner for Human Rights of the Council of Europe and the U.N. Special Rapporteur took the same line, opposing the position of the Ministry officials in the Council on the grounds that it would bring political influence. ${ }^{70}$

The problems posed by the existence of the Ministry in the Council were visible in the 2007 and 2010 crises when the Minister and the Undersecretary blocked the meetings of the

\footnotetext{
${ }^{66}$ As the statistics of the Council dated July 26, 2016 shows, 15.304 judges and prosecutors were serving in the country. http://www.hsk.gov.tr/Eklentiler/Dosyalar/39c8a8cb-7600-4159-933b-48881447f0d4.pdf.

67 Fazıl Sağlam, AKP'nin Anayasa Değişikliği Paketi Üzerine Düşünceler, 24 MüLKIYE DERGISı 267 (2010); Muharrem Özen, Yargı Bağımsızlığını Zedeleyen Düzenleme, Uygulamalar ve Bağımsızlığı Sağlamaya Yönelik Çözüm Önerileri, 68 Ankara Barosu DergISI 31 (2010); Burak Çelik, Yargı Reformu: Hedefler, Sorunlar, Öneriler, GünCEL HUKUK (2014); BURAK ÇElIK, HAKIMLER Ve SAVCILAR YÜKSEK KURULU: YAPISAL AÇIDAN KARŞILAŞTIRMALI BIR İNCELEME (2012) [hereinafter BURAK ÇELIK, HAKIMLER VE SAVCILAR YÜKSEK KURULU].

${ }^{68}$ Cemal Baltacı, Demokrasi ve Yargı Bağımsızlığı Bağlamında Türkiye'de Hakimler ve Savcılar Yüksek Kurulu, 14 CUMHURIYET ÜNIVERSITESI İKTISADI VE İDARI BILIMLER DERGISI (2013).

69 Id.

70 Report by Thomas Hammerberg Commissioner for Human Rights of the Council of Europe, Administrative of Justice and Protection of Human Rights in Turkey, CommDH(2012)2, (Jan. 10, 2012), par. 104 http://www.europarl.europa.eu/meetdocs/2009_2014/documents/d-tr/dv/0131_04/0131_04en.pdf; Gabriela Knaul, Report of the Special Rapporteur on the independence of judges and lawyers: Mission to Turkey, U.N. Doc. A/HRC/20/19/Add.3, (May 4, 2012), par. 32 http://www.ohchr.org/Documents/HRBodies/HRCouncil/Regula rSession/Session20/A-HRC-20-19-Add3_en.pdf; Kjell Bjönberg \& Paul Richmond, The Functioning of the Judicial System in the Republic of Turkey: Report of an Advisory Visit (28 September- 10 October 2003) http://www.abgm.adalet.gov.tr/avrupabirligi/turkyargisi/istisariziyaret/en/\%C4\%B0stisariZiyaretRaporu-2003en.pdf; Kjell Bjönberg \& Paul Richmond, The Functioning of the Judicial System in the Republic of Turkey: Report of an Advisory Visit (11-19 July 2004) https://ingel.home.xs4all.nl/ankara/advisory\%20report\%20II.pdf.
} 
Council. ${ }^{71}$ Before the 2010 amendments, the Council could not meet in the absence of the Undersecretary. ${ }^{72}$ In 2007, the Council could not meet to elect the members of the Court of Cassation and Council of State because of a disagreement between the Ministry and the judicial members of the Council on that matter. In 2010, further disagreement occurred with respect to the appointments and promotions of criminal judges and prosecutors with special powers. The judicial members of the Council preferred to wait until the result of pending investigations against those judges and prosecutors were known, prior to appointments. The Ministry withdrew the draft decree and left the meetings. The Decree as proposed by the Ministry was adopted right after the 2010 amendments by the new Council. $^{73}$

Some welcomed the 2010 amendments reducing the role of the Ministry into more of a symbolic presence, particularly by granting the Council institutional and budgetary autonomy. ${ }^{74}$ The Venice Commission, too, welcomed several aspects of the 2010 amendments such as "the wide transfer of power from the Ministry of Justice to the HSYK, both as regards legal competences, staff and resources" and "the substantial reduction in the power and position of the Minister for Justice as President." ${ }^{75}$ However, the Ministry, as the Chair of the Council, continued to hold important powers, such as to appoint the Secretary-General of the Council ${ }^{76}$, and to authorize disciplinary investigations of judges. ${ }^{77}$

${ }^{71}$ For a detailed examination of these crises see BURAK ÇELIK, HAKIMLER VE SAVCILAR YÜKSEK KURULU, supra note 67, at 193-197.

72 This was due to Article 10/1 and 2 of the previous Law on the High Council of Judges and Prosecutors (Law no. 2461). All the members of the Council could be replaced by the substitute members during the meetings, except for the Undersecretary. Since he/she could not be replaced, and the whole Council constituted a quorum, the Council was not able to meet in the absence of the Undersecretary. See BURAK ÇELIK, HAKIMLER VE SAVCILAR YÜKSEK KURULU, supra note 67, at 233.

73 Burak ÇELIK, HAKIMLER Ve SAVCILAR YÜKSEK KURULU, supra note 67, at 197.

74 ERgun ÖZBudun, Türk ANAYASA HUKUKu 394 (2016).

${ }^{75}$ Venice Commission, supra note 4, par. 27.

${ }^{76}$ Article $159 / 11$ of the 1982 Constitution.

${ }^{77}$ Article 159/9 of the 1982 Constitution. Such powers have raised concerns regarding judicial independence in the reports of Thomas Giegerich after his peer review missions to Turkey. See Thomas Giegerich, Peer Review Mission to Turkey: Report on Independence, Impartiality and Administration of the Judiciary (Aug. 1, 2011) http://avrupa.info.tr/fileadmin/Content/Downloads/PDF/2011_Peer_Review_Report_on_the_Independence_Im partiality_and_Administration_of_the_Judiciary.pdf; Thomas Giegerich, Peer Review Mission to Turkey: Report on the Turkish High Council of Judges and Public Prosecutors: Assessment of Its Initial Track Record of Operation, (Feb. 4, 2013) http://typo3.p147163.mittwaldserver.info/fileadmin/Content/Files/DelegationDocuments/en/Rep ort 04022013.pdf 
The powers of the Ministry during the candidacy and pre-service training of judges, particularly the oral examinations are seen as a further negative impact on judicial independence. The law graduates who pass the written examination are subject to an oral examination to become eligible for candidacy. The Board which conducts the oral exam consists of seven members, and five of them are the high-ranking officers of the Ministry of Justice. ${ }^{78}$ As of 2016, with the changes made on the powers of the Justice Academy, candidates are subject to a second oral examination again by a Board, which is dominated by members from the Ministry of Justice. ${ }^{79}$ Besides the concerns regarding the objectivity of these oral examinations, making young graduates at the beginning of their judicial careers meet high-ranking officers from the executive serves to create the culture of a dependent judiciary.

The latest constitutional amendments of 2017 pose additional concerns over judicial independence regarding the role of the President of the Republic. The function of the President in the Turkish constitutional system dramatically changed after the 2007 constitutional amendments which paved the way for a popularly elected President. ${ }^{80}$ As mentioned above, currently, the members of the Council are appointed by the President of Republic and the National Assembly. The Venice Commission in its recent report on the 2017 constitutional amendments highlighted a potentially dangerous scenario that would be seriously detrimental to judicial independence:

The Commission finds that the proposed composition of the CJP is extremely problematic. Almost half of its members $(4+2=6$ out of 13$)$ will be appointed by the President. It is important to stress once again in this respect that the President will no more be a pouvoir neutre, but will be engaged in party politics: his choice of the members of the CJP will not have to be politically neutral. The remaining 7 members would be appointed by the Grand National Assembly. If the party of the President has a three-fifths majority in the Assembly, it will be able to fill all positions in the Council. If it has, as is almost guaranteed under the system of simultaneous elections, at least two-fifths of the seats, it will be able to obtain several seats, forming a majority together with the presidential appointees. That would place the independence of the judiciary in serious jeopardy, because the CJP is the main self-governing

\footnotetext{
${ }^{78}$ Article $9(A) / 6$ of the Law on Judges and Prosecutors.

79 See the discussions above under the title of "The Justice Academy of Turkey".

${ }^{80}$ Law no 5678, enacted on October 21, 2007 amending article 101 of the 1982 Constitution.
} 
body overseeing appointment, promotion, transfer, disciplining and dismissal of judges and public prosecutors. ${ }^{81}$

\section{Judicial Self-Government and Judicial Accountability}

The 2010 amendments to the composition and powers of the Council influenced de jure judicial accountability by changing the actors to whom judges are accountable. Before, although the disciplinary sanctions were imposed by the Council, supervision, inspection, and any inquiries on the conduct of judges were carried out by the inspectors of the Ministry. Therefore, both the Council and the Ministry were the main actors in terms of accountability. With the establishment of the Board of Inspectors within the Council, the role of the Ministry as an accountability actor has been weakened. However, the Minister as the Chair of the Council holds the power to authorize investigations against judges. Another remarkable development influencing de jure judicial accountability is the return of the appeal evaluation form in 2016. In addition to enforcing a new accountability mechanism, the senior judges have been brought to the scene again as additional accountability actors.

The processes and mechanisms through which judges are held accountable can be divided into four categories: i) judicial performance evaluation system, ii) transfer of judges, iii) disciplinary sanctions, and iv) criminalization of the judiciary.

First, judicial performance evaluation is an essential part of the promotion of judges resting on a two-tiered system. Once a year, judges' grades are advanced (a type of promotion based on seniority); and once in two years, their degrees are promoted (a type of promotion based on merit). ${ }^{82}$ Time-lapses and the absence of any disciplinary sanctions are mutual requirements for both types. In addition to these requirements, for degree promotion, judges are evaluated based on their moral characteristics, professional knowledge, the quality and quantity of their work, the records and files prepared by the inspectors of the Council, their work reviewed by the supreme courts, and their in-service training. ${ }^{83}$ The 2010 amendments made the Council the sole authority to regulate and govern the performance evaluation system by creating the Board of Inspectors. In addition,

\footnotetext{
${ }^{81}$ Turkey: Opinion on the amendments to the constitution adopted by the Grand National Assembly on 21 January 2017 and to be submitted to a national referendum on 16 April 2017, Adopted by the Venice Commission at its 110th Plenary Session (Venice, 9-11 March 2017), European Commission for Democracy through Law (Venice Commission) (Mar. 13, 2017), par. 119.

${ }^{82}$ Article 18 of the Law on Judges and Prosecutors.

${ }^{83}$ Article 21 of the Law on Judges and Prosecutors.
} 
the Council publishes its own principles, which set out the exact number and percentages of cases to be completed by different types of courts in one period of evaluation. ${ }^{84}$

Secondly, judges are accountable through transfer of judges by the Council. This mechanism can be regarded as an accountability perversion since it is a mechanism that is not formally an accountability mechanism but is misused in a way that makes judges more accountable. ${ }^{85}$ Transfer of judges between districts derives from the socio-economic disparity between different regions of the country. Judicial organization in Turkey is divided into five districts which are ranked on the basis of financial and geographical conditions, and opportunities regarding transportation, health and cultural services. ${ }^{86}$

In principle, the transfer system is based on the period of service. The minimum period for service increases as the ranking of the district increases. While judges are required to stay a minimum of two years in the fifth district -the most inferior one-, the minimum period rises to seven years in the first district which includes more developed cities and municipalities. ${ }^{87}$ However, these time requirements are not treated as absolute rules. The Council can decide to transfer judges in special circumstances.$^{88}$ First, judges who cannot serve in dignity and impartially, as expected from the service, can be transferred to another district of the same level. Secondly, judges can be transferred due to their failure to meet the requirements of expedition and success. Thirdly, the Council has the power to transfer a judge to an inferior district as a de jure disciplinary measure. ${ }^{89}$ Apart from these special circumstances, judges themselves can request a transfer based on certain permissible factors limited to sickness, marriage, education, and natural disasters. ${ }^{90}$ The Council has the discretion to deny these requests.

\footnotetext{
${ }^{84}$ See Birinci Sınıfa Ayrılan ve Birinci Sınıf Olan Hâkim ve Savcıların Çalışmalarının Değerlendirilmesi Esaslarına Iliş̧kin Ilke Kararı (2017); Hakim ve Savcıların Derece Yükselmesi Esaslarına Illişkin İlke Kararı (2017).

${ }^{85}$ Transfer of judges as discussed here should not be confused with the change of location which is a formal disciplinary measure. The reasons for imposition of this measure are listed in Article 68 of the Law on Judges and Prosecutors.

${ }^{86}$ See Article 35/2 of the Law on Judges and Prosecutors; Article 2 of the Regulation on the Appointment and Transfer of Judges and Prosecutors.

${ }^{87}$ Article 3 of the Regulation on the Appointment and Transfer of Judges and Prosecutors.

${ }^{88}$ Article 7 of the Regulation on the Appointment and Transfer of Judges and Prosecutors.

${ }^{89}$ Article 68 of the Law on Judges and Prosecutors.

${ }^{90}$ Article 8 of the Regulation on the Appointment and Transfer of Judges and Prosecutors.
} 
The Council is the sole authority on transfer of judges. Between 2011-2016, the Council decided on more than twenty-two thousand transfers with an average of 3154 each year (see Chart 1). The lists of transferred judges are published; however, they do not include information regarding the reasons for the transfers, or whether the transfer was requested by the individual judge or not. In the absence of any concrete reasons and any judicial remedy against the decisions of the Council, the power to transfer judges can be used as a de facto accountability mechanism by the Council. Judges can be transferred involuntarily without due regard to the above mentioned formal requirements.

Chart 1. Transfer of Judges (2011-2017)

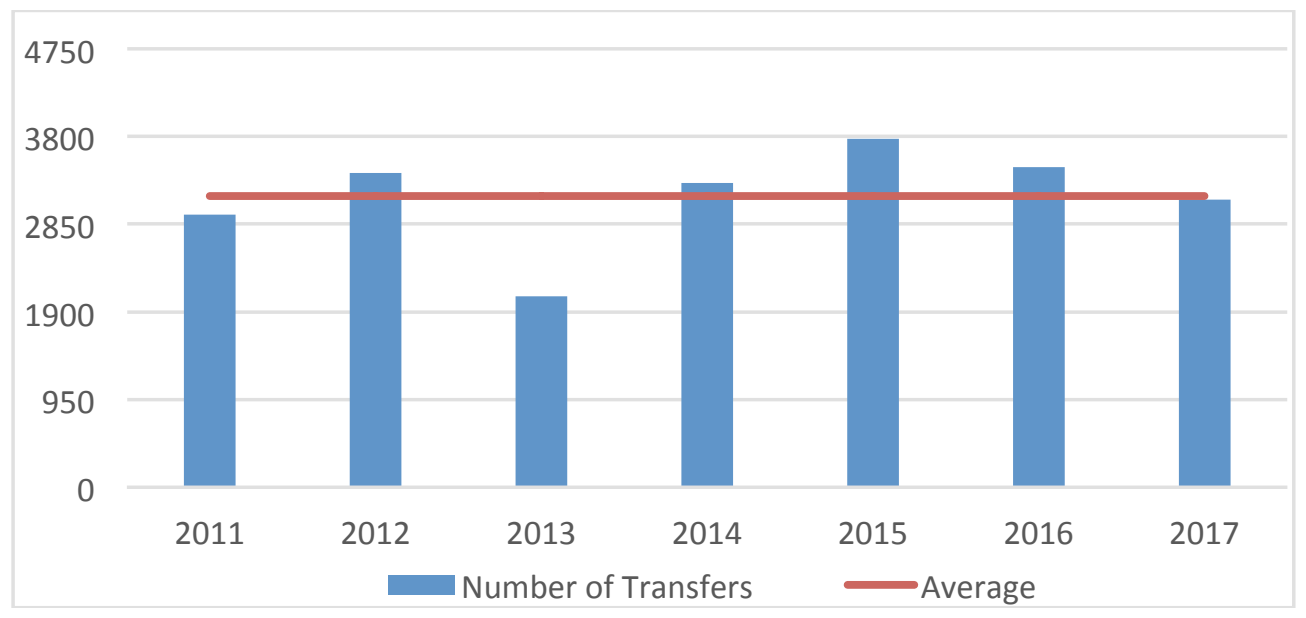

Thirdly, the disciplinary sanctions are listed as (a) warning; (b) cut from salary; (c) condemnation; (d) suspension of grade advance; (e) suspension of degree promotion; (f) change of location; and (g) dismissal from profession. ${ }^{91}$ The conditions that may result in the imposition of such disciplinary sanctions are also listed in the law. However, the vague wording of these conditions raises concerns. For instance, they include "improper conduct", "harming respect and trust required by the official position", "dressing inappropriately", "jeopardizing the harmony of the service." ${ }^{92}$ The Venice Commission highlighted the risk that these broad and vague conditions "could be used to sanction a

\footnotetext{
${ }^{91}$ Article 62 of the Law on Judges and Prosecutors.

92 Articles 62-69 of the Law on Judges and Prosecutors.
} 
judge whose judicial decisions are disliked, without explicitly referring to such a motive."193 The ECtHR case of Özpınar v. Turkey shows the impact of such vague wording on the private lives of the judges. In this case, a female Turkish judge was expelled from the office on the basis that she had engaged in "inappropriate acts and relationships detrimental to the dignity and respect of the profession", "wore too much make-up and dressed inappropriately", and was "creating an image that she did not respect her profession by acting based on her emotions". ${ }^{94}$ These vague conditions still remain in the Law, and the subsequent Law on the High Council of Judges and Prosecutors also adopted them.

Dismissal from office - the heaviest disciplinary sanction available - has been widely used during the state of emergency which was declared on 21 July 2016 in the aftermath of the coup attempt on 15 July 2016. The first State of Emergency Decree, gave the power to the (High) Council on Judges and Prosecutors to dismiss those judges and prosecutors "who are considered to be a member of, or have relation, connection or contact with terrorist organizations or structures, organizations or groups established by the National Security Council as engaging in activities against the national security of the State. ${ }^{\prime 95}$ Based on this provision, until October 2017, the Council dismissed 4279 judges and prosecutors in total for their alleged links with the Fetullahist Terrorist Organization. ${ }^{96}$

It must be noted that the Council issued nine decisions on the dismissals between August 2016 and May 2017, and each one has the exact same wording. The names of the judges and prosecutors dismissed are attached to each decision. The procedure applied in these decisions raised several concerns. First, it is not clear whether the conditions for dismissal are met in each individual case. Secondly, it is not known whether dismissed judges had an opportunity to defend themselves before the decisions are made pursuant to the procedural safeguards enshrined in the law. ${ }^{97}$ Thirdly, the evidence put forward by the Council in these decisions are not individualized, but mainly composed of general knowledge about how the Gulenists infiltrated the judiciary. The Council indicated that it

93 European Commission for Democracy through Law (Venice Commission), (Mar. 29, 2011), par. 59 http://www.europarl.europa.eu/meetdocs/2009_2014/documents/d-tr/dv/1128_17_/1128_17_en.pdf.

94 Özpınar v. Turkey, App. No. 20999/04 (Oct. 19, 2010), http://hudoc.echr.coe.int/eng?i=001-101220.

95 Article 3/1 of the State of Emergency Decree No. 667, enacted on July 23, 2016.

96 High Council of Judges and Prosecutors General Assembly Decision No. 2016/426, 24/8/2016; Decision No. 2016/428, 31/8/2016; Decision No. 2016/430, 4/10/2016; Decision No. 2016/440, 15/11/2016; Decision No. 2016/434, 29/11/2016; Decision No. 2017/35, 13/02/2017; Decision No. 2017/113, 17/03/2017; Decision no. 2017/665, 3/4/2017; Decision No. 2017/682, 05/05/2017.

97 Article 71 of the Law on Judges and Prosecutors sets out that no disciplinary action can be taken against judges in the absence of their defense. The judges shall be given at least three days for their defense. 
used "information and documents in personal employment files, posts in social media accounts, complaints, reports, examination and investigation files about the related individuals, which were received by the High Council of Judges and Prosecutors." ${ }^{98}$

Lastly, the phenomenon of criminalization of the judiciary, although not directly related to the changes in JSG arrangements, inevitably increased not only the accountability of the individual judges, but of the judiciary as a whole, including the JSG bodies themselves. As announced by the Ministry of Justice in July 2017, after the coup attempt, 2431 judges and prosecutors are under detention based on their alleged membership of the terrorist organization. These include 105 members of the Court of Cassation, 41 members of the Council of State, 2 members of the Constitutional Court, and 3 members of the High Council for Judges and Prosecutors. ${ }^{99}$

\section{Judicial Self-Government and Judicial Legitimacy}

The quality of judges and the quality of the recruitment process are the main social legitimacy concerns with the judiciary in Turkey. Recent developments concerning the dismissals and criminal prosecution of hundreds of judges raised important discussions on the social dimensions of judicial legitimacy.

The hijacking of the judiciary by a particular sectarian group highlights that the recruitment, admission, and training of judges lack quality, objectivity, and transparency. The Council itself admits such deficiencies in its decisions on the dismissals. ${ }^{100}$ As the Council indicated, the Fetullahist or Gulenist organization, with an aim to form a parallel state structure, used its members to infiltrate the military, security personnel, bureaucracy, and the judiciary. Accordingly, the organization had obtained the questions and answers of the written exams illegally and provided them to their members. They had been organized, particularly during the pre-service training period at the Justice Academy, and had stayed in clandestine houses together. The Council also argued that the members of this organization had been treated more favorably than others in terms of access to the education programs. They were also protected against disciplinary measures, and even used those measures to eliminate others who are outside the organization. The Council, at various parts in its decisions, confirmed that the Ergenekon and Sledgehammer cases were "fantasies" of this organization.

\footnotetext{
${ }^{98}$ The English translation of the General Assembly decision can be found here: http://www.judiciaryofturkey.gov .tr/pdfler/hsyk_karar440.PDF.

99 Hurriyet Daily News, More Than 154,000 faced legal probe over Gulen links since coup attempt (May 29, 2017) http://www.hurriyetdailynews.com/more-than-154000-faced-legal-probe-over-gulen-links-since-coup-attempt-113663

${ }^{100}$ See the High Council for Judges and Prosecutors General Assembly Decisions, supra note 96.
} 
These decisions amount to the Council admitting that the previous Council which served from 2010 until 2014 "was mainly composed of FETO/PDY members." According to the Council, the organization took over the previous Council after the 2010 amendments which made the first category judges and prosecutors eligible for the Council's membership via peer elections. The opposing narrative, however, argues that this was possible only through an alliance between these judges and the AKP government.

The intensive measures taken to purge this sectarian group, however, did not put an end to the legitimacy concerns particularly regarding the quality and objectivity of the recruitment process. Since the quarter of the judiciary had been dismissed from the profession, the immediate response of the government to fill these positions has been to enable the candidate judges to be recruited, "regardless of the time they spent in the internship." ${ }^{101}$ In addition, the minimum grade (70 points) necessary in the written examination to be eligible for the candidacy was removed. ${ }^{102}$

\section{Judicial Self-Government and Judicial Transparency}

In Turkey, information is available and publicly accessible on matters of general court administration. The Ministry of Justice, the Council and the Academy issue online annual reports at the end of each year providing information about the activities of each administrative unit within these institutions, including the use and allocation of their own budget. The annual reports of the Council indicate the number of decisions issued by each chamber, the number of complaints received, gender segregated statistics on the personnel, and the number of judges and prosecutors admitted to the profession each year. Additionally, all these three institutions publish strategy plans for four year-periods.

Information regarding judicial transfers, appointments and evaluation criteria is also available. The Council sets the standards for appointments, transfers and performance evaluation through its own regulations and principle decisions which are easily accessible online. However, as discussed in the context of judicial accountability, information becomes less available and findable when it is personalized. In other words, while the information is available regarding the general standards for promotions, it is not possible to reach information about the specific reasoning behind the promotion of a particular

\footnotetext{
${ }^{101}$ Article 3/2 of the State of Emergency Decree no 667 (adopted on 23/7/2016).

${ }^{102}$ Article 6 of the State of Emergency Decree no 680 (adopted on 6/1/2017) amending article 9/A of the Law on Judges and Prosecutors.
} 
judge. Even the individual judges themselves are not able to reach this information since some parts of information are kept in the confidential performance evaluation files. ${ }^{103}$

The major change regarding judicial transparency was brought in 2010 regarding the decisions on disciplinary measures. Before 2010, whether and which disciplinary measure was imposed to individual judges was not accessible publicly. In 2010, the Law on the Council for Judges and Prosecutors required the decisions on the disciplinary measures to be put on the website of the Council. ${ }^{104}$

\section{Judicial Self-Government and Public Confidence in the Judiciary}

In a jurisdiction like Turkey where there have been short-lived experiments concerning the governance of the judiciary, it is a difficult task to trace the impacts of each and every judicial development on public confidence.

The surveys conducted on the trust in the Turkish judiciary (see Chart 2 and Chart 3, below) provide differing findings, but share a common result. Between 2010 and 2013, there was a decline in the percentage of trusting respondents. This decline may be the result of the 2010 constitutional amendments which brought radical changes in the judiciary, notably on the composition and powers of the Council, and the Constitutional Court. The narrative regarding these changes as a court-packing plan might have influenced public perception. On the other hand, an alternative narrative would argue that these surveys corresponded with the period when the judiciary was being controlled by the Gulenist organization, and when the mega cases, like Ergenekon and Sledgehammer, were still ongoing.

\footnotetext{
${ }^{103}$ Article 59 of the Law on Judges and Prosecutors.

${ }^{104}$ Article 32 (4) (b) of the Law on the Council for Judges and Prosecutors.
} 
Chart 2. Trust in the Turkish Judiciary (I)

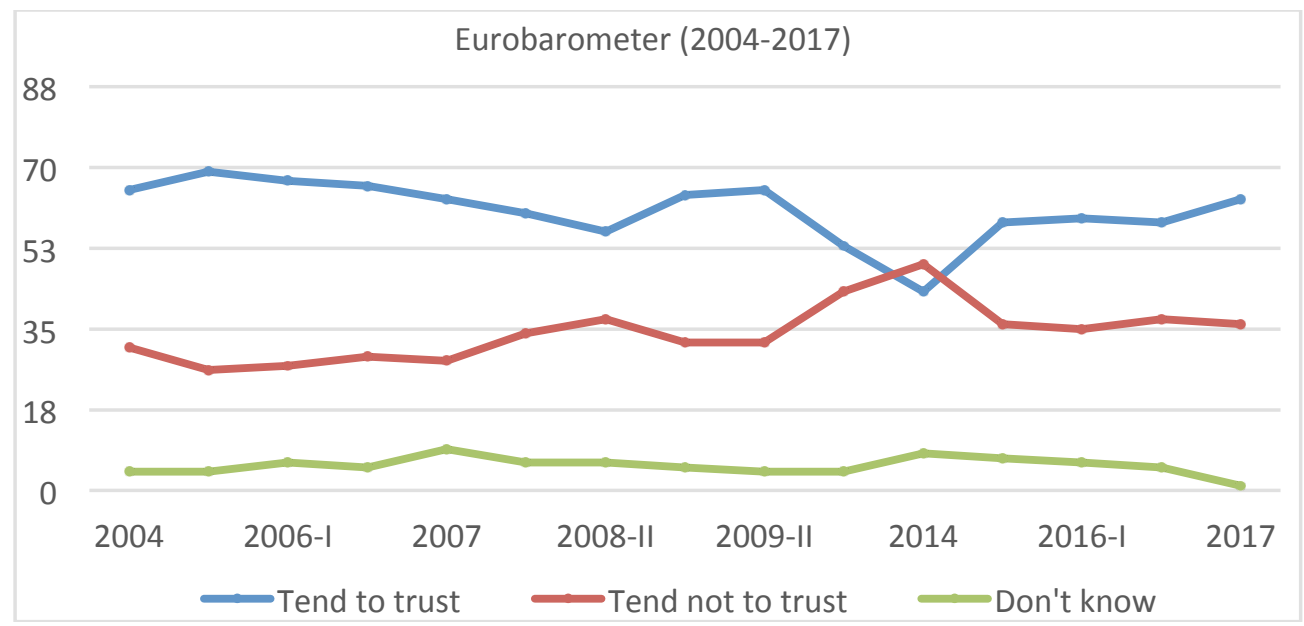

Chart 3. Trust in the Turkish Judiciary (II)

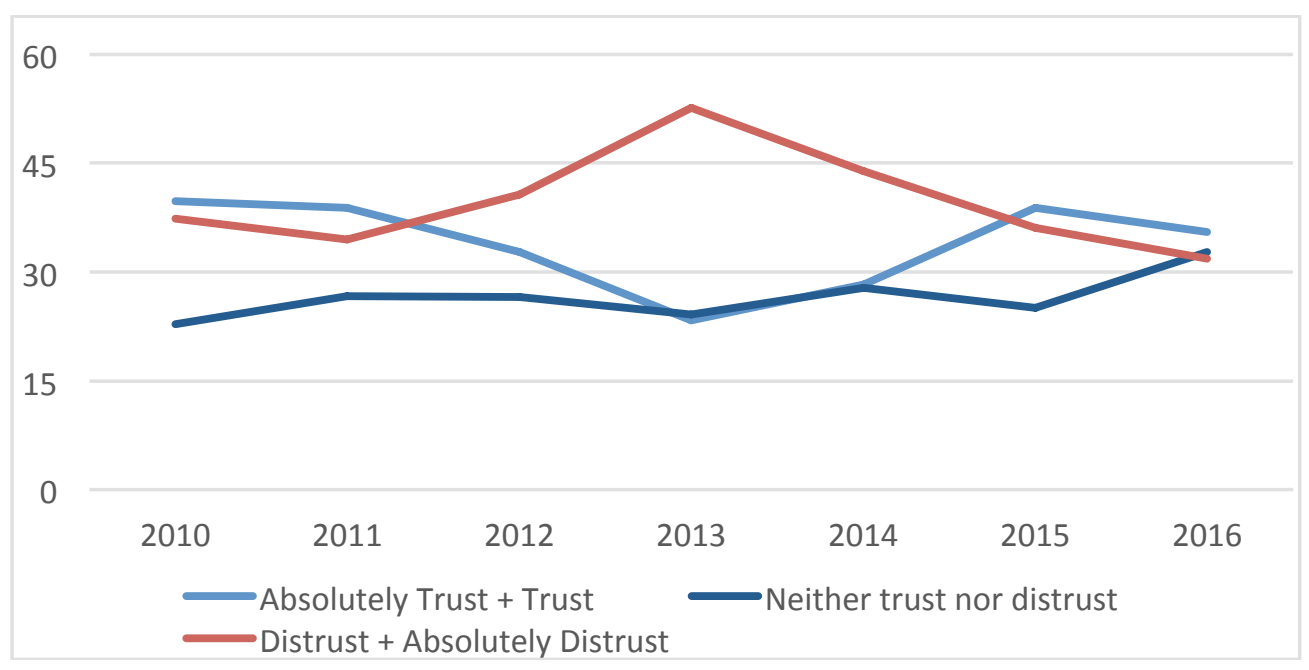

Source: Kadir Has University Social and Political Inclination Survey (2010-2016) 


\section{Repercussions of Judicial Self-Government for the Principle of Separation of Powers and the Democratic Principle}

The composition and powers of the Council and the Academy, and how their members are appointed or elected have had significant repercussions on the debates concerning the principle of separation of powers in Turkey. The ambiguous position of the Council and whether it is part of the judiciary as such or an extension of the administrative branch attracted much attention. Debates on the democratic principle, on the other hand, have focused on whom the Council represents - junior or senior members of the judiciary - and to what extent it enjoys democratic legitimacy.

\section{Separation of Powers}

The establishment of the Judicial Council and the insulating of powers related to the career of judges from the domain of the executive is a major development in ensuring the formal separation of powers in Turkey. Although this separation was blurred with the inclusion and ex officio memberships of the Minister and the Undersecretary to the Council in 1971 and 1982 respectively, the institutional and budgetary autonomy brought by the 2010 amendments further strengthened the separation between the judiciary and the executive. The 2010 amendments, however, were also described as informally increasing the control of the executive over the Council. Serious criticisms were raised with respect to the election of the first category judges and prosecutors among their peers. It was argued that the right of junior judges to stand for election to the Council would make them more dependent on the executive at the beginning of their career, and could result in them being easily manipulated. ${ }^{105}$ It was also seen as a part of the Justice and Development Party's alliance with junior judges against senior judges who were perceived as biased against the government. ${ }^{106}$

The Constitution regulates the Council under the general title of "judicial power". Once set up, the Council exercises its functions "in accordance with the principles of the independence of the courts and the security of the tenure of judges."107 However, upon closer look the Council also serves administrative functions when abolishing a court or

\footnotetext{
105 Fazıl Sağlam, supra note 67; LEVENT GÖNENÇ, DÜNYADA VE TÜRKIYEDE YÜKSEK YARGı KURULLARı (2011).

${ }^{106}$ Ayşe Aslıhan Çelenk, The myth of 'independent judiciary': the evolution of judiciary-executive relations in Turkish politics, 22 CONTEMPORARY POLITICS 232, 243 (2016).

107 Article 159/1 of the 1982 Constitution; Article 1 of the Law on the High Council of Judges and Prosecutors.
} 
changing the territorial jurisdiction of a court. ${ }^{108}$ The 2014 legal changes also enabled the Council to issue regulations and circulars on judicial matters. ${ }^{109}$

Despite the significant judicial and administrative powers, most decisions of the Council are not subject to judicial review. In the pre-2010 period, all the decisions of the Council were left outside the scope of judicial review. ${ }^{110}$ The 2010 amendments set out that only the decisions of the Council concerning the dismissal of judges are subject to judicial review. ${ }^{111}$ The limited scope of the judicial review of the Council has been criticized by Turkish scholars as well as the Venice Commission. ${ }^{112}$ The lack of judicial review of the decisions of the Council also means that the decisions of the Minister of Justice acting as the Chair of the Council cannot be reviewed by courts. Neither the Constitution nor the Law on the High Council of Judges and Prosecutors clarify whether the Council is an administrative organ or not. The Council may even be described as a super-administrative organ since most of its decisions are not subject to judicial review.

\section{Democratic Principle}

The Council had a hierarchical co-option model until the 2010 constitutional amendments, meaning that it was composed only of senior judges. Several scholars opposed to the composition of the Council in such a way, argued that it results in a "caste system"113 and "judicial technocracy." 114 It was also argued that the co-option model "facilitated the imposition of an ideological litmus test on judicial promotions, ensuring that the high judiciary was a relatively politically homogeneous group." ${ }^{115}$ Based on similar concerns, the

\footnotetext{
108 Article $159 / 8$ of the 1982 Constitution.

${ }^{109}$ Article 7/2(।) of the Law on the High Council of Judges and Prosecutors as amended by the Law no. 6524.

110 Prior to 2010, the only remedy to challenge the decisions of the Council was an internal commission within the Council. However, the commission was not considered as an effective remedy by the European Court of Human Rights. See Kayasu v. Turkey, App. No. 64119/00 and 76292/01, (Nov. 13, 2008), http://hudoc.echr.coe.int/eng?i=001-89606; Özpınar v. Turkey, supra note 94.

${ }^{111}$ Article $159 / 10$ of the 1982 Constitution.

112 BuRAK ÇELIK, HAKIMLER Ve SAVCILAR YüKSEK KURULU, supra note 67, at 353; Interim Opinion on the Draft Law on Judges and Prosecutors of Turkey, CDL-AD(2011)004, Venice Commission, supra note 93, par. 76; See also Venice Commission (2010), supra note 4, par. 55.

113 Serap Yazıcı, Turkey's Constitutional Amendments: Between the Status Quo and Limited Democratic Reforms, 12 INSIGHT TURKEY (2010) http://file.insightturkey.com/Files/Pdf/insight_turkey_vol_12_no_2_2010_yazici.pdf.

${ }^{114}$ Cemal Baltacı, supra note 68

115 Aslı Bâli, supra note 34.
} 
2010 amendments brought a more pluralistic and non-hierarchical model for the Council and thus arguably democratized the formation of the Council.

The 2017 amendments envisage the President and the Parliament sharing the task of the formation of the Council. Several scholars have suggested that having members elected by the Parliament would make the Council democratically legitimate. ${ }^{116}$ They argued that this has been recommended by the Consultative Council of European Judges (CCEJ). However, it is not the case. ${ }^{117}$ According to the CCEJ,

If in any state any non judge members are elected by the Parliament, they should not be members of the Parliament, should be elected by a qualified majority necessitating significant opposition support, and should be persons affording, in the overall composition of the Council for the Judiciary, a diverse representation of society. ${ }^{118}$

The 2017 constitutional amendments granted the power to the National Assembly to elect seven members of the Council, four from the judiciary, and three among the lawyers and law professors. The procedure prescribed by the Constitution is as follows:

The Joint Committee shall elect three candidates for each vacancy with a two-thirds majority of total number of members. If the procedure of electing candidates cannot be concluded in the first round, a three-fifth majority of total number of members shall be required in the second round. If the candidates cannot be elected in this round as well, the procedure of electing candidates shall be completed by choosing a candidate by lot, for each membership among the two candidates who have received the highest number of votes. The Grand National Assembly of Turkey shall hold a secret ballot election for each candidate the Committee has identified. In the first round a two-thirds majority of total number of members shall be required; in case the election cannot be concluded in this round, in the second round a three-fifth majority of total number of members shall be required. Where the member cannot

\footnotetext{
${ }^{116}$ Serap Yazıcı, Yüksek Yargı Konseylerinin Oluşturulmasında Demokratik Temsil ilkesi, in YARGıNıN BAĞıMSızLıĞı, TARAFSıZLIĞı VE ETKILILIĞı (Ahmet Taşkın ed. 2009); Yusuf Şevki Hakyemez, Hakimler ve Savcılar Yüksek Kurulu, in STRATEJIK DÜŞÜNCE ENSTITÜSÜ YARGI RAPORU: DEMOKRATIKLEŞME SÜRECINDE YARGI KURUMLARI (2010).

117 BuRAK ÇELIK, HAKIMLER Ve SAVCILAR YÜKSEK KURULU, supra note 67, at 129.

118 Opinion no.10 (2007) of the Consultative Council of European Judges (CCJE) to the attention of the Committee of Ministers of the Council of Europe on the Council for the Judiciary at the service of society (Nov. 23, 2007), par. 32.
} 
be elected in the second round as well, the election shall be completed by choosing a candidate by lot among the two candidates who have received the highest number of votes. ${ }^{119}$

Regarding the non-judge members, it can be said that the procedure is compatible with the opinion of the CCEJ as it included a qualified majority until the last round. It should be noted that the recommendation of the CCEJ concerns the non-judge members. The judge members, on the other hand, are recommended to be elected by their peers. ${ }^{120}$ The system brought by the 2017 amendments also allows the parliament to elect four members from within the judiciary. This option posed serious concerns that the election by the parliament would politicize the judiciary. It has been argued that the involvement of the Parliament in the elections would incentivize judges to build close relationships with parties, and act based on their interests after he or she got the membership. ${ }^{121}$

\section{E. Conclusion}

In this article we argued that JSG experimentalism in Turkey is linked to critical constitutional junctures in Turkish politics and is a manifestation of the high, but shifting, political stakes. The judicial powers have been vested in a Council since 1961 with the aim of insulating judicial matters from the executive domain, but the composition and the powers of the Council have seen significant changes over time. The Justice Academy has also not been safe from this experimentalism as it has experienced two major changes, only ten years after its establishment.

It has, therefore, been suspect, whether the different forms of JSG have promoted judicial independence, given the highly politicized conditions that led to many of the JSG reforms. The changes on the Council - except the financial and institutional autonomy introduced in 2010 - has often been seen as interfering with judicial independence due to the increased role of the Ministry of Justice. The concerns over judicial independence also exist regarding the changes to the Justice Academy, increasing the influence of the Ministry over the recruitment process. In the context of the 2017 constitutional reforms, which have moved Turkey from a parliamentary democracy to a form of presidentialism, where the power is highly centralized in the hands of a partisan leader, credible doubts exist regarding the Council's independence from the executive.

\footnotetext{
${ }^{119}$ Article 159/3 of the 1982 Constitution as amended on April 16, 2017.

${ }^{120}$ Opinion no. 10 (2007) of the CCEJ, supra note 116, par. 27.

${ }^{121}$ These concerns have been raised even before the 2017 amendments in Fazıl Sağlam, supra note 67; Muharrem Özen, supra note 67.
} 
Judicial accountability continues to be based on the centralized system of performance evaluation, transfers, and disciplinary supervision. Except for the power of the Minister of Justice to authorize disciplinary investigations, the Council stands as the most powerful actor holding individual judges accountable. In more recent times, the decisions of the Council on dismissals and criminal prosecutions, under the state of emergency regime, have changed the processes through which judges and the judiciary are held accountable. The infiltration of the judiciary by a group, followed by the purge of the quarter of the judiciary, including the members of the Council, has undoubtedly had effects on judicial legitimacy and public confidence.

The different models of JSG ranging from co-option or pluralistic, to hierarchical or nonhierarchical have had implications for the democratic principle. The power vested in the Parliament to elect the members of the Council by the recent constitutional amendments revived the debates on whether that would increase the democratic legitimacy or politicize the judiciary. 
